Funicle joints 2 and 3 each shorter than I, and 3 shorter than 2 ; each about as broad as is joint $I$ at tip. Club distinctly 3 -jointed, a little broader than funicle joint 3 ; joints $I$ and 2 of club subequal in length and each as long as funicle joint 3 . Joint 3 of club about as long as 2 , somewhat narrower at base than 2, pointed at tip. In other respects resembles Coccophagus, except that the hind tibiae are considerably flattened and have a row of short stiff bristles above. Middle tibial spur long and slender, nearly as long as first tarsal joint.
Aneristus ceroplastae, n. sp.-Female. Length, $.8 \mathrm{~mm}$.; expanse, $1.6 \mathrm{~mm}$.; greatest width of forewings, $.27 \mathrm{~mm}$. Mesonotum finely and closely shagreened, with sparse, rather long dark pile; eyes hairy; color black, slightly shining, all coxae and femora black; front and middle tibiae and all tarsi pallid, hind tibiae black. Wings with a very large discal infuscated patch, covering nearly half the wing area.

Described from 2 specimens reared by T. D. A. Cockerell from Ceroplastes on Euphorbia hypericifolia from Jamaica.

L. O. Howard.

\title{
X. Preliminary Diagnoses of New Coccidae.
}

\section{BY T. D. A. COCKERELL.}

The writer having lately prepared descriptions of various new Coccidae, which will appear in sundry bulletins, reports, proceedings of local societies, and so forth, it is deemed expedient to bring together some account of them here. This is done for the convenience of students, who sometimes complain of the difficulty of keeping track of scattered descriptions; and also to secure earlier publication, as some of the fuller accounts may be (indeed, have already been) much delayed. While the full details are not now given, there is sufficient descriptive matter, it is hoped, for the ready identification of the species. The species collected in Japan by $\mathrm{Mr}$. Takahashi were obtained for the Department of Agriculture and transmitted to me by Mr. L. O. Howard. Those collected by Prof. C. H. T. Townsend are also the property of the Department. Those obtained by Mr. Craw were collected at San Francisco in the course of his quarantine work. Full particulars concerning all of the Takahashi, Townsend and Craw species will be given in a forthcoming Bulletin of the Department of Agriculture. The West Indian forms will probably receive full publication in Trinidad.
Dactylopius olivaceus, n. sp. $-q$ long. $3 \frac{1}{2}$, lat. $2 \frac{1}{2}$, alt. I $\frac{1}{2} \mathrm{~mm}$. (in alcohol). Dark olivebrown, with mealy powder. Legs shorter than their distance from one another, very stout, coxa extremely large, digitules all filiform. Antennae brown, slender, 8-jointed, 8 very long. Formula 8 (123) (67) 54. Hairs of anal ring very small. Posterior tubercles obsolete. On Yucca, Ciudad Perfirio Diaz, Mexico (Townsend). Rather like D. glaucus, Maskell.

Eriococcus dubius, n. sp. $-q$ with sac a little over $3 \mathrm{~mm}$. long, sac loosely felted, white, with a slightly yellowish tinge. Dried \& very dark reddish-purple. Antennae 7-jointed, formula 34 (12) 756. Legs moderately slender, digitules ordinary. Posterior tubercles small but cylindrical. On some shrub, Valles, Mexico (Townsend). Very near to $E$. coccinens, Ckll., but apparently distinct.

Phenacoccus pergandei, n. sp. $-q$ with sac $8 \mathrm{~mm}$. long, 3 broad. Sac white, firm, partly overlapping the wrinkled orangebrown $q$. Antennae 9-jointed, formula 32 (14569) (78). Tarsus less than half as long as tibia. Digitules of claw of fair size, expanding rather gradually to their bulbous 
ends. Claw long, not much curved. On leaves of "Gumi," Japan (Takahashi). It has much the appearance of Pulvinaria camellicola.

Conchaspis angraeci v. hibisci, v. nov.Scale perhaps a little larger, grayish-white, with the apex tilted over on to the side. Strong ridges, about 3 in number, run from the apex towards the opposite margin. Antennae 4-jointed. On Hibiscus sp., Tamaulipas, Mexico (Townsend).

Lecaniodiaspis (Prosopophora) quercus, n. sp. - $q$ scale long. $3 \frac{1}{2}$, lat. $2 \frac{1}{2}$, alt. $2 \frac{1}{8} \mathrm{~mm}$., pale ochreous, obscurely carinate, segmentation fairly evident. Antennae 7 -jointed, formula (34) (25) (67) 1. On 2uercus sp., Tokio, Japan (Takahashi). Very like $P$. rufescens, but more convex. It might be taken at a glance for an Eriococcus, being about the color of the sacs of E. eucalypti, Mask.

L. (P.) celtidis, n. sp. $-q$ scale long. 3 , lat. $2 \frac{1}{2}$, alt. I $\frac{1}{2} \mathrm{~mm}$., broad-oval, convex, above very light ochreous, conspicuously frosted with white secretion. Antennae 8-jointed, formula 4 (35) (6I) (72) 8. Eggs pale pink. On Celtis occidentalis, San Antonio, Texas (Townsend). The eggs in $L$. yuccue are yellowish.

Sphaerococcus (Pseudolecanium, $n$. subg.) tokionis, n. sp.- Scale irregular, more or less oval, about $6 \mathrm{~mm}$. long, dark brown, shiny, producing a little cottony matter. The adult $q$ is simply a sac full of larvae; the margin has well-developed capitate spines. Larvae suggesting those of Kermes. Cephalic end with a row of about ro tubular glands, hind extremity with blunt spines. On twigs of bamboo, Japan (Takahashi). Rather like S. bambusae, Mask., but not showing the distinct caudal segments of that insect.

Lecanium imbricatum, n. sp.- + scale about $4 \mathrm{~mm}$. long, oval, moderately convex, reddish-brown, much wrinkled when dry; more or less covered, especially at sides, with a thin, fragile glassy coat. Derm thickly beset with large brown glands, which viewed laterally are broadly fusiform. Anal ring with 8 long hairs. Antennae very short, thick, rudimentary, joints not distirguishable. Legs rudimentary, very short and stout. $\delta$ scales as usual in genus, rugose. On Mimosa, Alta Mira, Mexico (Townsend). Belongs to a neotropical group.

L. nanum, n. sp. $-q$ scale like a very small $L$. hesperidum, thus like $L$. minimum, Newst., but antennae 7 -jointed, joints obscure, formula 3 (27) 14 (56). Derm with small scattered round gland-dots, legs very small, the four digitules about of equal size, those of tarsus not extending beyond those of claw. Anal plates short and broad, redbrown. With young Icerya rosae in covered runs of an ant on leaves of "Balata," Trinidad (Hart). The $\$ s$, though so small, contained embryos.

Pulvinaria aurantii, n. sp.-Looks like $P$. psidii, Mask., but that has the marginal spines more numerous and very much smaller, the femur and trochanter larger, etc. In aurantii the antennae are 8-jointed, 3 longest. Legs ordinary, tarsus much shorter than tibia, digitules of claw very large and stout, with large knobs. Rostral loop very short. On orange, Tokio, Japan (Takahashi).

P. broadwayi, n. sp. $-q$ reddish-brown, about $\mathrm{I} \frac{1}{2} \mathrm{~mm}$. long in shrivelled condition, on and surrounded by an oval cushion of white secretion, about $3 \mathrm{~mm}$. long. Antennae 8-jointed, formula 3 (28) (4I) (56) 7. Legs rather stout and large, tibiotarsal articulation unusually distinct. Claw strong, much curved. Digitules of claw stout, extending beyond its tip, with large knobs; tarsal digitules slender, nearly twice as long as those of claw. Margin with very numerous stout but rather short pale brown spines. On twigs of a plant not identified, but seemingly Anacardiaceous, Botanic Gardens, Grenada (Broadway). Sent by Mr. Urich. Easily known by the cottony matter surrounding the $q$. 
P. (Takahashia, n. subg.) japonica, n. sp. - A most extraordinary species, with the ovisac enormously elongating, lifting the of insect into the air, so that the whole might be compared to a bent finger, the nail represented by the $q$. Antennae short and stout, 7 -jointed, 3 much longest, formula 3 (7I) (25) (46). Tarsal digitules extending about as far as tip of claw, digitules of claw extending a little beyond. The length of the ovisac is about $\mathrm{r} 7 \mathrm{~mm}$. On Mulberry, Tokio, Japan (Takahashi).

Ceroplastes mexicanus, n. sp.- Scale with wax long. 6 , lat. 5 , alt. $3 \frac{1}{2} \mathrm{~m} \mathrm{~m}$.; wax rather thin, grayish-white with an ochreous tinge, smooth, without noticeable ridges or grooves, separated into plates, the sutures between the plates not differently colored from the rest of the wax. Plate-nuclei small, dull dark purplish with a central spot of white secretion. Antennae apparently 7-jointed, formula 43 (12) (567). Digitules of claw stout, with large round knobs. Caudal horn rudimentary; dorsum of $q$ simply convex. On Catalpa, San Luis Potosi, Mexico (Townsend). Somewhat allied to $C$. cirripediformis, Comst.

Aspidiotus townsendi, n. sp. $-q$ scale II $\frac{1}{2} \mathrm{~mm}$. diam., circular or slightly oval, quite flat, thin, grayish-white or nearly transparent; exuviae central or nearly so, covered, round, pale orange, with the first skin sublateral on the second. $\delta$ scale similar but smaller and elongate, with the exuviae towards one end. $\&$ orange, subcircular, sometimes reniform, 4 groups of ventral glands, cephalolaterals 4 to 8 , caudolaterals 5. Two pairs of rounded lobes, median largest, not contiguous. Plates forming a scaly fringe. Piedras Negras, Mexico, on leaves of an undetermined plant (Townsend). Near to $A$. uvae, Comst.

A. nigropunctatus, n. sp. $-q$ scale subcircular to suboval, $3 \mathrm{~mm}$. diam., only slightly convex, dirty gray; exuviae sublateral, pitch black, with a narrow reddish margin. Exuviae covered by a film of white secretion, easily deciduous. $\&$ orangebrown, oval, 5 groups of ventral glands, 4 pairs of lobes, saccular glands between the lobes, many oval dorsal pores. Median lobes close together but not touching. Plates not conspicuous. On bark of some tree, San Luis Potosi, Mexico (Townsend). Near to A. obscurus, Comst.

A. yuccae, n. sp. $-q$ scale small, about I $\mathrm{mm}$. or a little more in diameter, oval, moderately convex, dirty whitish, with the covered inconspicuous pale brown exuviae to one end. When rubbed, the exuviae appear shiny dark brown or black, very conspicuous. o nearly circular, 3 pairs of lobes, all low; the median ones largest, rounded, broad, not contiguous, the other two pairs rudimentary. Spine-like plates, much longer than the lobes. Anal orifice less than its length from hind end. No grouped ventral glands seen. On Yucca, Cindad Porfirio Diaz, Mexico (Townsend). Near to $A$. bowreyi, Ckll.

A. duplex, n. sp. $-q$ scale about $2 \frac{2}{3} \mathrm{~mm}$. diam., subcircular, moderately convex. dark blackish-brown with the large round exuviae nearly to one side and orange. $\&$ pale orange, 4 pairs of lobes, the median very large, with parallel sides, the others small; plates scale-like. 5 groups of ventral glands, caudolaterals of about 3 , cephalolaterals 42 , median 2. Tokio, Japan ('Takahashi). Near to $A$. theae, Mask. A. duplex was also found by Mr. Ehrhorn on camellia in a Japanese nursery at San Francisco, and by Mr. Craw on orange trees from Japan.

A. secretus, n. sp. - $\uparrow$ scale white, shiny, exuviae shiny, very pale yellow, rather large, not covered, placed to one side. $q$ nearly round, mouth-parts far posterior; 3 pairs of lobes, median large, strongly diverging, and lobes obscurely trilobed, 3 rd lobe a long way from the second. Apparently no plates, and no groups of ventral glands. Crowded under the epidermis of bamboo, Tokio Japan (Takahashi).

A. albopunctatus, n. sp. or var. $-\delta$ scale 
black, conspicuous, exuviae marked by a white dot surrounded by a whitish ring. $q$ scale extremely inconspicuous. No groups of ventral glands. 2 pairs of lobes. On twigs of orange seediings from Japan (Craw). In all its characters this is almost exactly like $A$. perniciosus, and would have been assumed to be that but for the locality and food-plant. It is another "physiological species,"like A. coloratus or the West Indian form of $A$. aurantii. The true perniciosus never attacks orange trees in California, nor is it found on the deciduous fruit-trees from Japan which have passed through Mr. Craw's hands, nor in Takahashi's collections.

Chionaspis difficilis, n. sp. $-q$ scale about $2 \mathrm{~mm}$. long, irregular, from round to subelongate, moderately convex, white; exuviae to one side, 2 nd skin black or nearly so, ist skin pale straw yellow. $\delta$ scale white, tricarinate. $\&$ orange-rufous, becoming bluish-green when boiled in soda. 5 groups of ventral glands, caudolaterals 43 , cephalolaterals 4I-43, median about 37 . Median lobes large, diverging; second and third lobes notched; plates spine-like, large. On Elaeagnus from Japan (Craw). This is a very Diaspis-like Chionaspis.

C. latus, n. sp.-Allied to C. braziliensis, with a tricarinate white $\delta$ scale, and a broad pyriform red-brown $q$ scale. The broad flat scale readily distinguishes it. On leaves of orange, Tokio, Japan (Takahashi).

C. bambusae, n. sp. - + scale white, elongate-pyriform, exuviae pale straw yellow, second skin with an orange spot at the tip. In size, shape and color it is like $C$. vaccinii, but it differs in the number of glands in the ventral groups, etc. On leaves of bamboo, Tokio, Japan (Takahashi).

Mytilaspis carinatus, n. sp. $-q$ scales something like $M$. citricola, but narrower and with a pronounced median longitudinal keel. 4 groups of ventral glands, of about 4 orifices each. Lobes small. Some large spine-like plates. Saccular glands along the pygidial margin. Rows of elongate pores marking the obsolete segments. On a plant like Anthurium from Central America (Craw).

M. crawii, n. sp. $-q$ scale narrow, about $2 \frac{1}{3} \mathrm{~mm}$. long and $\frac{1}{2} \mathrm{~mm}$. wide, slightly curved, pale orange yellow, exuviae concolorous. Four groups of ventral glands, caudolaterals of 3 , cephalolaterals of 4 . Median lobes very large, rounded at ends, their edges finely serrate. Beneath the epidermis of leaves of Elaeagnus from Japan (Craw).

Parlatoria theae, n. sp.- $q$ scales on bark, very inconspicuous, about $\mathrm{I}_{3}^{2} \mathrm{~mm}$. long, oval in outline, slightly convex, pale ochreous, with the and skin black or nearly so. Removed from the twig they leave a white mark. o (after boiling) colorless, lobes pale ochreous. Median lobes trilobed. 4 groups of ventral glands, with a single median one. Caudolaterals 8, cephalolaterals 20 . On tea-plant, Japan (Takahashi).

$P$. theae var. viridis $\mathrm{v}$. nov. vel $\mathrm{n}$. sp. $-q$ scale about $\mathrm{I} \frac{1}{2} \mathrm{~mm}$. long, nearly circular; but the exuviae projecting at one side. Scale white with a more or less pronounced grayish yellow tinge, exuviae dark greenish to black. o (in soda) bluish-green with the pygidial area pale orange and the region about the mouth suffused with brown. Five groups of ventral glands, caudolaterals 16 to $\mathrm{I} 7$, cephalolaterals 9 to 16 , median $I$ to 4 . On bark of twigs of an ornamental plant from Japan (Craw). The tips of the median lobes are more produced than in theae.

\section{Some Species of Oxybelus Found in New Mexico.}

$$
\text { BY T. D. A. COCKERELL AND C. F. BAKER. }
$$

Oxybelus quadricolor, n. sp.- Female : About to $\mathrm{mm}$. long, black with red and creamy-white markings, strongly punctured. Head rather large, somewhat broader than 

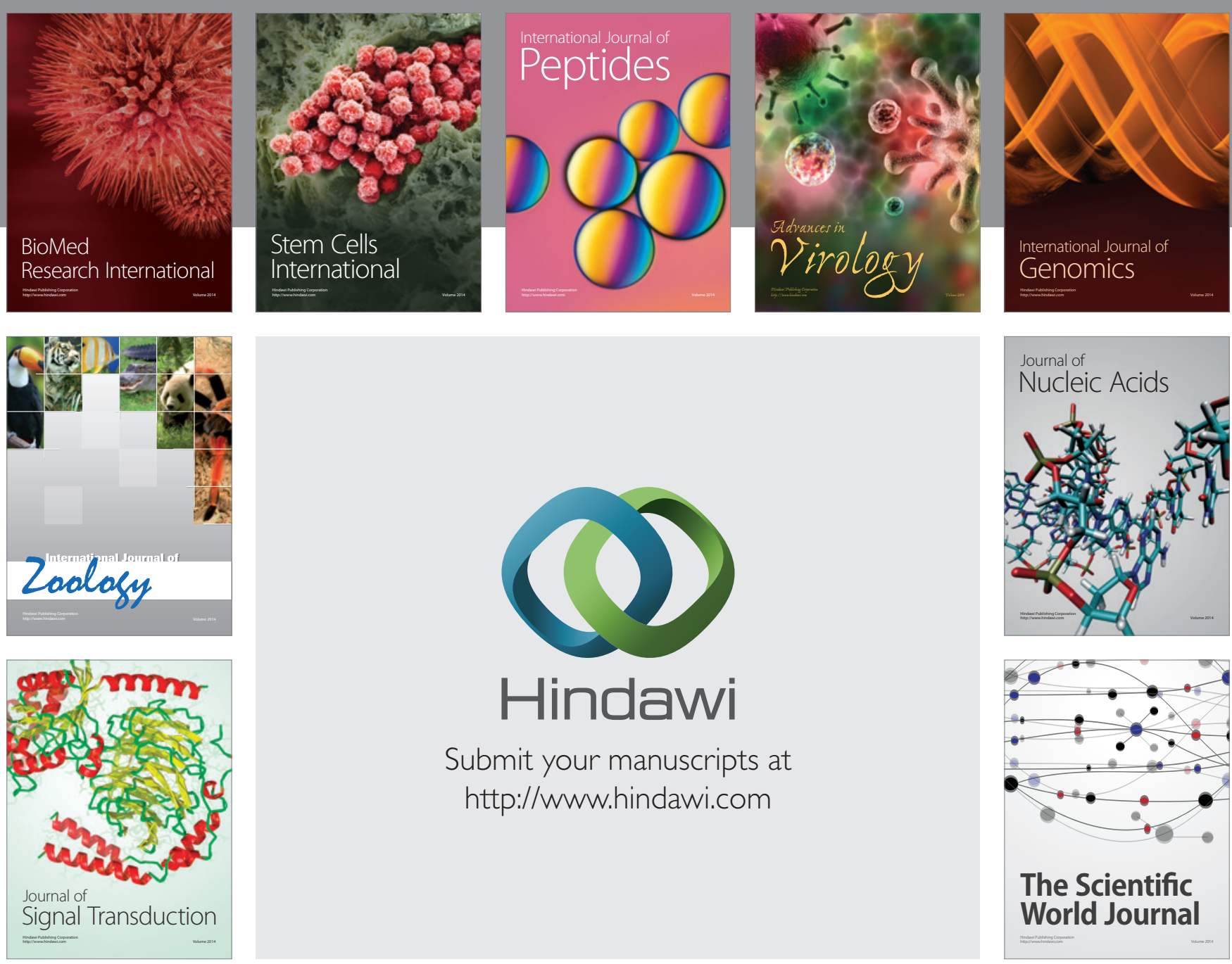

Submit your manuscripts at

http://www.hindawi.com
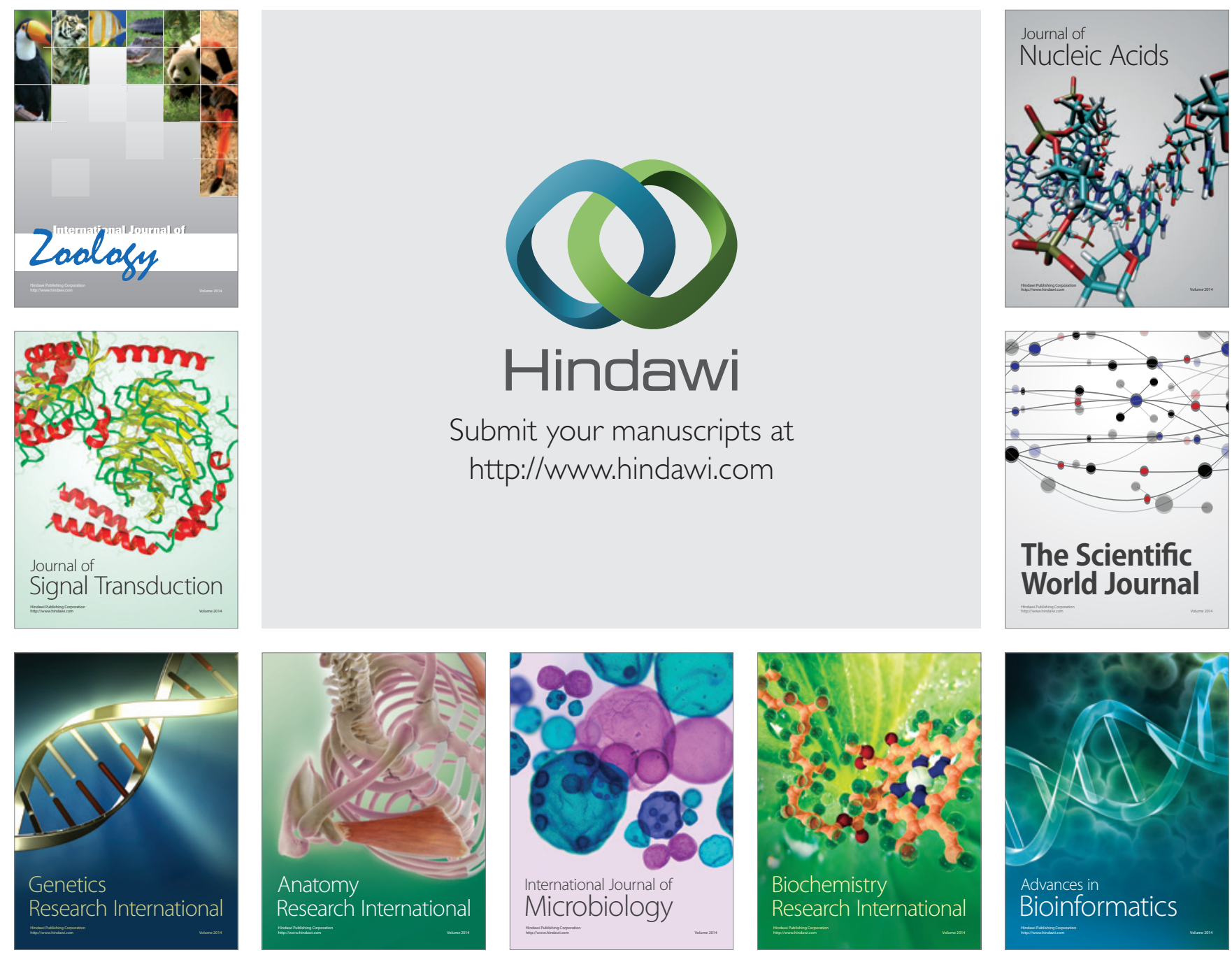

The Scientific World Journal
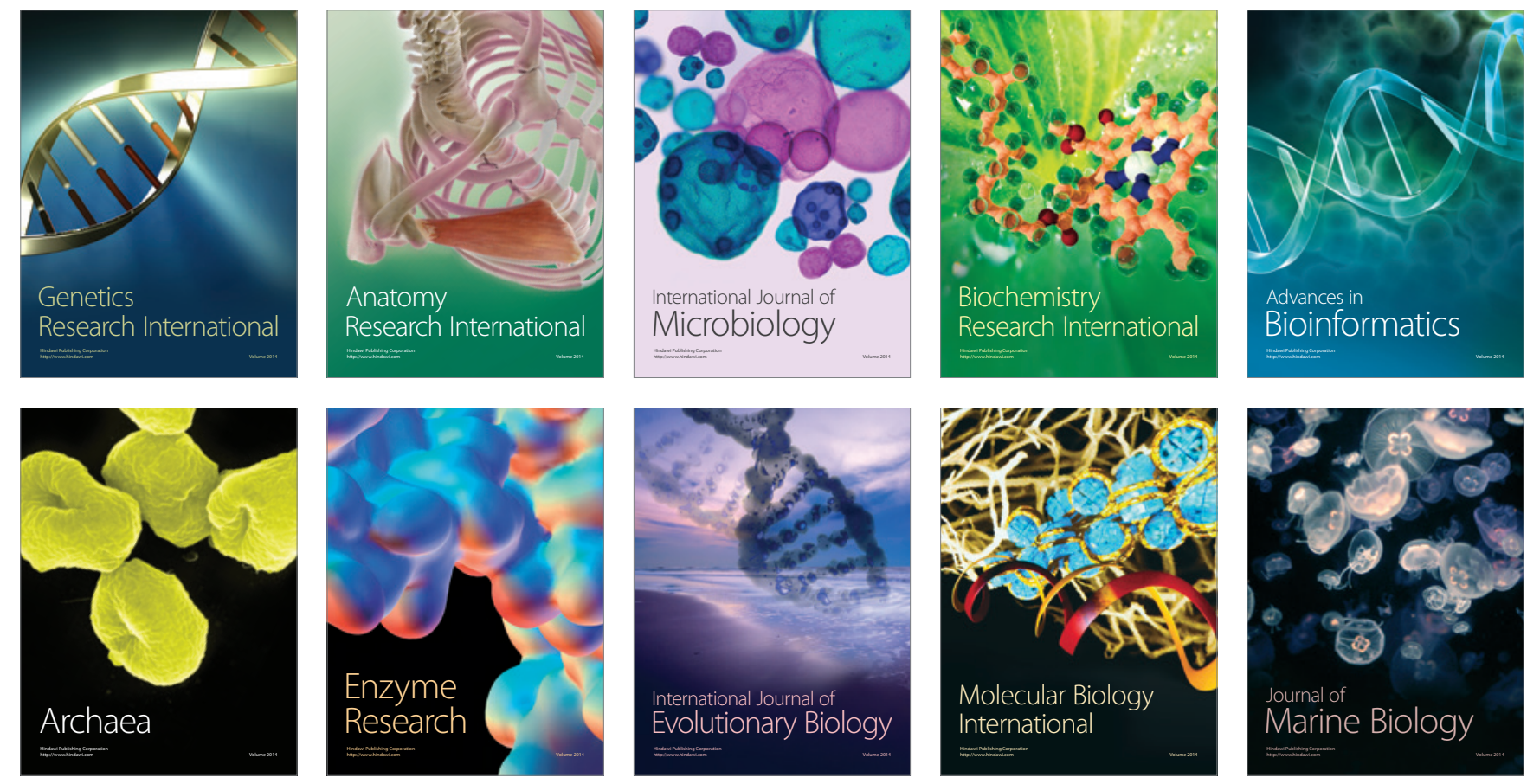